Fonathan Swift 
This page intentionally left blank 


\section{Jonathan Swift}

H IS LIFE AND HIS WORLD

Leo Damrosch

Yale UNIVERSITY PRESS

New Haven and London 
Published with assistance from the Annie Burr Lewis Fund and from the foundation established in memory of Philip Hamilton McMillan of the Class of I894, Yale College.

Copyright (C) 2013 by Leo Damrosch. All rights reserved. This book may not be reproduced, in whole or in part, including illustrations, in any form (beyond that copying permitted by Sections 107 and 108 of the US Copyright Law and except by reviewers for the public press), without written permission from the publishers.

Yale University Press books may be purchased in quantity for educational, business, or promotional use. For information, please e-mail sales.press@yale .edu (US office) or sales@yaleup.co.uk (UK office).

Designed by Nancy Ovedovitz and set in Adobe Garamond type by Newgen North America. Printed in the United States of America.

Library of Congress Cataloging-in-Publication Data

Damrosch, Leopold.

Jonathan Swift : his life and his world / Leo Damrosch.

pages $\mathrm{cm}$.

Includes bibliographical references and index.

ISBN 978-0-300-I6499-2 (clothbound : alk. paper)

I. Swift, Jonathan, I667-I745. 2. Authors, lrish-I8th century-

Biography. I. Title

PR3726.D27 20I3

$828^{\prime} .509-\mathrm{dc} 23$

[B]

A catalogue record for this book is available from the British Library.

This paper meets the requirements of ANSI/NISO Z39.48-1992

(Permanence of Paper).

I0 $98765432 \mathrm{I}$ 